\title{
GOAT COLOSTRUM-SOURCE OF TOXIGENIC BACILLUS CEREUS
}

\author{
Bursová, S. ${ }^{1}$, Nečasová, D. ${ }^{1}$, Dorotíková, K. ${ }^{2}$, Necidová, L. ${ }^{1}$, Vorlová, L. ${ }^{1}$ \\ ${ }^{1}$ Department of Milk Hygiene and Technology \\ ${ }^{2}$ Department of Gastronomy, Faculty of Veterinary Hygiene and Ecology \\ University of Veterinary and Pharmaceutical Sciences Brno, Palackého tř. 1946/1, 61242 Brno \\ Czechia
}

bursovas@vfu.cz

\section{ABSTRACT}

The aim of this study was to evaluate the toxigenic potential of Bacillus cereus strains isolated from frozen goat colostrum. Of the $\mathbf{5 0}$ phenotypically suspected B. cereus isolates, $39(78.0 \%)$ were confirmed as $B$. cereus by the polymerase chain reaction (PCR) method based on the gyrB gene detection. In these isolates, genes encoding the production of haemolysin $\mathrm{BL}(\mathrm{Hbl})$, a complex of non-haemolytic enterotoxins (Nhe) and emetic toxin were detected by the PCR method. In $36(92.3 \%)$ confirmed $B$. cereus isolates, genes encoding at least one type of toxins of interest were detected. In all toxigenic isolates, we found the presence of genes for Nhe production, and in $16(41.0 \%)$ of the isolates, genes encoding both Nhe and haemolysin BL were shown. Eight (20.5\%) of the emetic strains of $B$. cereus were identified. The emetic toxin production gene was always detected simultaneously with genes encoding non-haemolytic enterotoxin production. The ability to produce $\mathrm{BL}$ haemolysin and non-haemolytic enterotoxins were confirmed by the immunochromatographic method. In summary, goat colostrum can be a significant source of toxigenic strains of $B$. cereus.

Key words: cereulide; haemolysin BL; non-haemolytic enterotoxin; PCR

\section{INTRODUCTION}

Bacillus cereus is a Gram-positive, facultative anaerobic, and spore-forming rod. As a soil associated ubiquitous organism, B. cereus is commonly found in food products where they can cause spoilage [6]. B. cereus is the causative agent of two different types of food-borne illnesses: the emetic syndrome, caused by ingestion of a preformed emetic toxin (cereulide) in the food, and the diarrheal syndrome, caused by different toxins that can be formed in the food but also in the small intestine [5, 8]. The occurrence of these diseases are mainly associated with the consumption of foods made from cereals and potatoes, as well as vegetable dishes, minced meat dishes, milk and rice [8]. 
The diarrheal syndrome has been associated with three toxins: a single protein named cytotoxin $\mathrm{K}$, and two heatlabile complexes-haemolysin BL and non-haemolytic enterotoxin (both composed of three protein components). The emetic syndrome is caused by the heat-resistant toxin cereulide [6].

As evidenced by a number of studies, raw milk, dairy products and dairy farm environments are a common source of toxigenic $B$. cereus $[4,5,6,12,13,15]$. Simultaneously, psychrotrophic $B$. cereus strains capable of growing at temperatures below $8{ }^{\circ} \mathrm{C}$ can also be isolated [16]. The incidence of $B$. cereus in raw milk can be dramatically affected by the housing conditions [4]. Milk and dairy products are more commonly associated with the occurrence of a diarrheal form of the disease [10]. Nevertheless, in comparison with other food matrices the risk of toxin-induced diarrheal illness through consumption of contaminated milk may be limited [5]. According to a study of $\mathrm{M}$ a et al. [13], B. cereus was the dominant bacterial species found in goat milk powder (42.22\% from 249 identified species). The high occurrence of $B$. cereus in raw goat milk has also been shown in a study by $\mathrm{Zh}$ a $\mathrm{n}$ g et al. [23].

The objective of our study was to evaluate the toxigenic potential of B. cereus strains isolated from frozen goat colostrum samples.

\section{MATERIALS AND METHODS}

\section{Bacterial strains}

A total of 186 samples of frozen goat colostrum obtained from a local producer of food supplements were examined for the presence of Bacillus cereus. The individual samples of goat colostrum were collected from goats from different herds (accurate data were not provided by the producer). The samples ( $25 \mathrm{~g}$ ) were incubated at $37^{\circ} \mathrm{C}$ for $24 \mathrm{~h}$ in $225 \mathrm{ml}$ of Buffered Peptone Water (Oxoid Ltd, Basingstoke, Hampshire, UK). The enriched samples were inoculated onto Mannitol Yolk Polymyxin B agar (MYP; HiMedia Laboratories Pvt. Ltd., Mumbai, India) and incubated at $30{ }^{\circ} \mathrm{C}$ for $24 \mathrm{~h}$. A total of 50 (26,9\%) phenotypically suspected $B$. cereus strains (appeared as colonies with typical morphology on MYP agar and complete haemolysis on blood agar) were obtained and included in the study.

\section{DNA isolation}

For DNA isolation, colonies grown on blood agar plates were used (after incubation at $30^{\circ} \mathrm{C}$ for $24 \mathrm{~h}$ ). The DNA isolation was carried out by means of heating the bacterial cells in $200 \mu \mathrm{l}$ sterile saline at $100{ }^{\circ} \mathrm{C}$ for $20 \mathrm{~min}$ with consecutive centrifugations at $10660 \times \mathrm{g}$ for $6 \mathrm{~min}$. The supernatant was used as a template.

\section{Polymerase chain reaction}

The polymerase chain reaction (PCR) was used for species confirmation and detection of genes encoding emetic toxin (cereulide), non-haemolytic enterotoxin (Nhe) and haemolysin $\mathrm{BL}(\mathrm{Hbl})$. A total of 4 multiplex polymerase chain reactions (mPCR) were carried out with specific primers to detect gyrB gene and toxicity determined by various $B$. cereus genes. The $16 \mathrm{~S}$ rRNA gene was targeted as an internal control gene in the presence of bacterial DNA. The sequences of the primers used are given in the Table 1, the composition of the reaction mixture was adapted to PPP Master Mix use (Top-Bio, Ltd., Prague, Czech Republic). A total reaction volume of $25 \mu \mathrm{l}$ was made up of $23 \mu \mathrm{l}$ of the master mix and $2 \mu$ of the template DNA. Amplification was performed on a PTC-200 thermocycler (MJ Research Watertown, Massachusetts, USA).

PCR 01: This was used for the detection of the gyrase B gene (B. cereus species confirmation), gene encoding the non-ribosomal peptide synthetase (which plays a role in the production of emetic toxin) and the highly conserved regions of the bacterial 16S rRNA (internal control). The PCR amplification involved: the initial denaturation step of $10 \mathrm{~min}$ at $95^{\circ} \mathrm{C}$, followed by 30 cycles, each including $1 \mathrm{~min}$ of denaturation at $94^{\circ} \mathrm{C}, 1 \mathrm{~min}$ of annealing at $54^{\circ} \mathrm{C}$, 1 min of elongation at $72^{\circ} \mathrm{C}$, and the completion with a final elongation at $72{ }^{\circ} \mathrm{C}$ for $5 \mathrm{~min}$.

PCR 02: This was used for the detection of the hblA and hblC genes encoding the production of haemolysin BL. The PCR amplification involved: the initial denaturation step of 4 min at $94^{\circ} \mathrm{C}$, followed by 36 cycles, each including $30 \mathrm{~s}$ of denaturation at $94^{\circ} \mathrm{C}, 1 \mathrm{~min}$ of annealing at $62.5^{\circ} \mathrm{C}, 1 \mathrm{~min}$ of elongation at $72{ }^{\circ} \mathrm{C}$, and the completion with a final elongation at $72{ }^{\circ} \mathrm{C}$ for $7 \mathrm{~min}$.

PCR 03: This was used for the detection of the nheA and nheC genes encoding production of the non-haemolytic enterotoxin. The PCR amplification involved: the initial denaturation step of $2 \mathrm{~min}$ at $94^{\circ} \mathrm{C}$, followed by 
Table 1. PCR primers used in the study

\begin{tabular}{|c|c|c|c|c|c|c|}
\hline $\begin{array}{l}\text { Target } \\
\text { gene }\end{array}$ & Primer & $\begin{array}{l}\text { Primer sequence } \\
\qquad\left(5^{\prime}-3^{\prime}\right)\end{array}$ & $\begin{array}{l}\text { Amplicon } \\
\text { size [bp] }\end{array}$ & Reference & Annealing & PCR \\
\hline \multirow[t]{2}{*}{ gyrB } & $\mathrm{BC} 1$ & ATT GGT GAC ACC GAT CAA ACA & 365 & Yamada et al. (1999) [22] & $54^{\circ} \mathrm{C}$ & BC 01 \\
\hline & $\mathrm{BC} 2$ & TCA TAC GTA TGG ATG TTA TTC & & & & \\
\hline \multirow[t]{2}{*}{ NRPS* } & CER1 & ATC ATA AAG GTG CGA ACA AGA & 188 & Horwood et al. (2004) [11] & $54^{\circ} \mathrm{C}$ & BC 01 \\
\hline & CER2 & AAG ATC AAC CGA ATG CAA CTG & & & & \\
\hline \multirow[t]{2}{*}{ 16Sr RNA } & InKo1 & GGA GGA AGG TGG GGA TGA CG & 241 & Martineau et al. (1996) [14] & $54^{\circ} \mathrm{C}$ & BC 01 \\
\hline & InKo2 & ATG GTG TGA CGG GCG GTG TG & & & & \\
\hline \multirow[t]{2}{*}{ hblA } & HBLA1 & GCT AAT GTA GTT TCA CCT GTA GCA AC & 873 & Rowan et al. (2003) [17] & $62.5^{\circ} \mathrm{C}$ & $\mathrm{BC} 02$ \\
\hline & HBLA2 & AAT CAT GCC ACT GCG TGG ACA TAT AA & & & & \\
\hline \multirow[t]{2}{*}{$h b / c$} & HBLC-N & AAT AGG TAC AGA TGG AAC AGG & 399 & Rowan et al. (2003) [17] & $62.5^{\circ} \mathrm{C}$ & $\mathrm{BC} 02$ \\
\hline & HBLC-C & GGC TTT CAT CAG GTC ATA CTC & & & & \\
\hline \multirow[t]{2}{*}{$h b l D$} & HBLD-N & AAT CAA GAG CTG TCA CGA AT & 439 & Rowan et al. (2003) [17] & $54^{\circ} \mathrm{C}$ & BC 04 \\
\hline & HBLD-C & CAC CAA TTG ACC ATG CTA AT & & & & \\
\hline \multirow[t]{2}{*}{ nheA } & nheA344S & TAC GCT AAG GAG GGG CA & 499 & Ghelardi et al. (2002) [7] & $54^{\circ} \mathrm{C}$ & $\mathrm{BC} 03$ \\
\hline & nheA843A & GTT TTT ATT GCT TCA TCG GCT & & & & \\
\hline \multirow[t]{2}{*}{ nhe $B$} & NBF & TTT AGT AGT GGA TCT GTA CGC & 743 & Guinebretière et al. (2002) [9] & $54^{\circ} \mathrm{C}$ & BC 04 \\
\hline & NBR & TTA ATG TTC GTT AAT CCT GC & & & & \\
\hline \multirow[t]{2}{*}{ nheC } & NCF & TGG ATT CCA AGA TGT AAC G & 683 & Guinebretière et al. (2002) [9] & $54^{\circ} \mathrm{C}$ & $\mathrm{BC} 03$ \\
\hline & NCR & ATT ACG ACT TCT GCT TGT GC & & & & \\
\hline
\end{tabular}

*NRPS—non-ribosomal peptide synthetase

35 cycles, each including $1 \mathrm{~min}$ of denaturation at $94^{\circ} \mathrm{C}$, 1 min of annealing at $54^{\circ} \mathrm{C}, 2 \mathrm{~min}$ of elongation at $72^{\circ} \mathrm{C}$, and the completion with a final elongation at $72{ }^{\circ} \mathrm{C}$ for $5 \mathrm{~min}$.

PCR 04: This was used for the detection of the nheB gene (non-haemolytic enterotoxin) and hblD gene (haemolysin $\mathrm{BL}$ ). The PCR amplification involved: the initial denaturation step of $2 \mathrm{~min}$ at $94^{\circ} \mathrm{C}$, followed by 35 cycles, each including $1 \mathrm{~min}$ of denaturation at $94^{\circ} \mathrm{C}, 1 \mathrm{~min}$ of annealing at $54^{\circ} \mathrm{C}, 2 \mathrm{~min}$ of elongation at $72^{\circ} \mathrm{C}$, and the completion with a final elongation at $72{ }^{\circ} \mathrm{C}$ for $5 \mathrm{~min}$.

The amplified products were separated by electrophoresis on a $2 \%$ agarose gel in $0.5 \times$ TBE buffer, followed by consecutive staining with ethidium bromide and visualization on a UV transilluminator.

\section{Duopath ${ }^{\circledast}$ Cereus Enterotoxins GLISA}

The ability of the strains to produce the diarrheal enterotoxins of Nhe and $\mathrm{Hbl}$ were verified by the use of the commercially available Duopath ${ }^{\circledast}$ Cereus Enterotoxins GLISA immunoassay kit (Merck KGaA, Darmstadt, Germany). The tests were performed according to the manufacturer's instructions. A strain was considered positive if the red lines appeared on both of the test and control zones.

\section{RESULTS}

Out of the 50 phenotypically suspected B. cereus isolates included in the study, 39 (78\%) were confirmed by the PCR method as B. cereus. In 36 (92.3\%) of the iso- 
lates, the genes encoding for the production of at least one type of the toxins of interest were detected. The detection of genes encoding $\mathrm{Nhe}, \mathrm{Hbl}$ and emetic toxin (cereulide) production were performed only in the confirmed B. cereus isolates. The summary of the results is given in Fig. 1 and Table 2.

At the same time, genes encoding the production of all three toxins (cereulide, Hbl, Nhe) were not detected in any of the isolates. As shown in Fig. 1, the detection rate of non-haemolytic enterotoxin genes among all B. cereus positive isolates was $30.8 \%$ (12 isolates). In 16 (41.0\%) of the $B$. cereus isolates, genes encoding both non-haemolytic enterotoxin (Nhe) and haemolysin $\mathrm{BL}(\mathrm{Hbl})$ production were shown.

In our study, all 3 genes (hblA, hblC, and hblD) encoding the individual components of this toxin were always detected simultaneously. However, there was observed a different variability of the nheA, nheB and nheC genes in the goat colostrum B. cereus isolates (Table 2). Genes encoding all three components of both haemolysin BL (hblACD) and non-haemolytic enterotoxin (nheABC) were detected simultaneously only in six B. cereus isolates (15.4\%). In all potentially enterotoxigenic strains of $B$. cereus, the immu- nochromatographic method confirmed the ability to produce the observed enterotoxins.

A total of 8 (20.5\%) emetic strains of B. cereus were detected (Table 2). The emetic toxin production gene was always detected simultaneously with genes encoding for the production of a complex of non-haemolytic enterotoxins (Figure 1).

\section{DISCUSSION}

The genes nhe encoding non-haemolytic enterotoxin are thought to be present in all B. cereus strains [20]. Also, other studies have confirmed the high proportion of nhe genes in toxigenic B. cereus isolated from food $[4,9,19]$. The results of our work confirmed these assumptions.

The $\mathrm{Hbl}$ enterotoxin complex consists of B, L1 and L2, and its enterotoxigenic activity appears when all 3 components of the $\mathrm{Hbl}$ complex are present $[2,18]$. In our study, the simultaneous presence of all hblA, hblC, and hblD genes encoding the production of haemolysin $\mathrm{BL}$ was demonstrated in $41 \%$ of the B. cereus isolates, always in combination with genes for non-haemolytic enterotoxin.

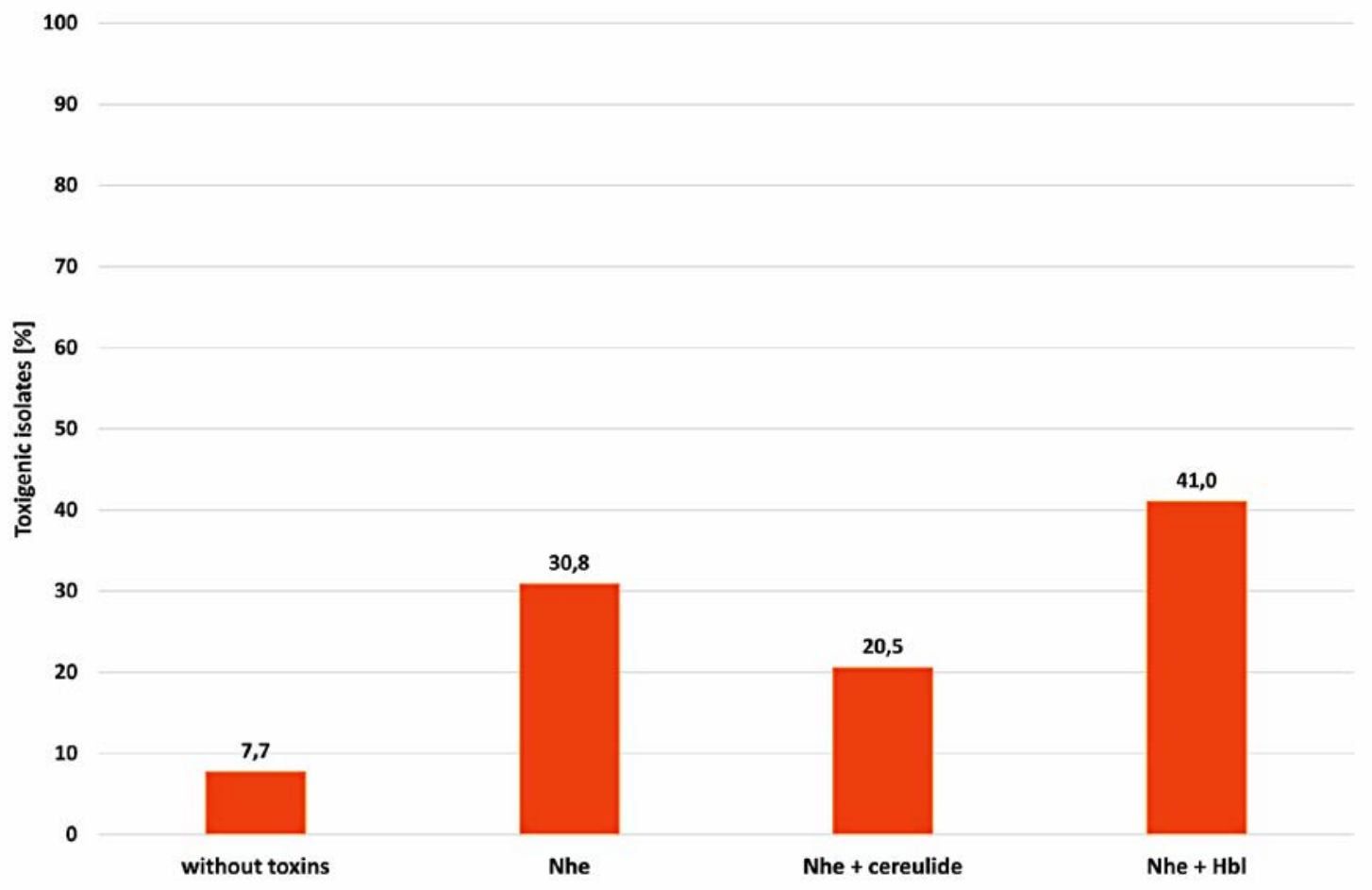

Fig. 1. Toxigenic potential of $B$. cereus isolated from goat colostrum $(n=39)$ Nhe-non-haemolytic enterotoxin; Hbl-haemolysin BL; cereulide-emetic toxin 
Table 2. Detection of toxin-encoding genes in B. cereus isolated from goat colostrum $(n=39)$

\begin{tabular}{|c|c|c|c|c|c|c|c|}
\hline \multirow{2}{*}{ Isolate } & \multirow{2}{*}{$\begin{array}{c}\text { Cereulide } \\
\text { cer } \\
\end{array}$} & \multicolumn{3}{|c|}{ Haemolysin BL } & \multicolumn{3}{|c|}{ Non-haaemolytic enterotoxin } \\
\hline & & hbla & hblc & hblD & nheA & nheB & nheC \\
\hline BC 505 & - & + & + & + & + & + & + \\
\hline BC 506 & + & - & - & - & + & + & + \\
\hline BC 507 & - & + & + & + & + & + & + \\
\hline BC 508 & + & - & - & - & + & - & + \\
\hline BC 511 & - & - & - & - & - & + & + \\
\hline BC 512 & + & - & - & - & + & + & + \\
\hline BC 513 & - & - & - & - & - & - & - \\
\hline BC 515 & - & - & - & - & - & - & - \\
\hline BC 516 & - & - & - & - & + & - & + \\
\hline BC 518 & + & - & - & - & + & + & + \\
\hline BC 519 & - & + & + & + & + & + & - \\
\hline BC 520 & - & + & + & + & + & + & - \\
\hline BC 521 & + & - & - & - & + & - & + \\
\hline BC 522 & - & + & + & + & + & - & + \\
\hline BC 523 & - & + & + & + & + & + & - \\
\hline BC 524 & - & + & + & + & + & - & + \\
\hline BC 525 & - & - & - & - & - & + & + \\
\hline BC 526 & - & + & + & + & + & - & + \\
\hline BC 527 & - & + & + & + & + & - & + \\
\hline BC 531 & + & - & - & - & + & + & + \\
\hline BC 533 & - & + & + & + & + & + & + \\
\hline BC 534 & + & - & - & - & + & + & + \\
\hline BC 536 & - & - & - & - & - & + & + \\
\hline BC 537 & - & + & + & + & + & + & + \\
\hline BC 539 & - & + & + & + & + & + & - \\
\hline BC 540 & - & - & - & - & + & + & + \\
\hline BC 541 & - & - & - & - & + & + & + \\
\hline BC 542 & + & - & - & - & + & + & + \\
\hline BC 543 & - & - & - & - & - & - & - \\
\hline BC 544 & - & + & + & + & + & + & + \\
\hline BC 546 & - & - & - & - & + & - & + \\
\hline BC 549 & - & + & + & + & + & - & + \\
\hline BC 550 & - & + & + & + & + & + & + \\
\hline BC 552 & - & - & - & - & + & + & + \\
\hline BC 553 & - & - & - & - & + & + & + \\
\hline BC 554 & - & - & - & - & - & + & - \\
\hline BC 556 & - & - & - & - & - & + & - \\
\hline BC 557 & - & - & - & - & - & + & + \\
\hline BC 558 & - & + & + & + & + & - & + \\
\hline Total (\%) & $8(20.5)$ & $16(41.0)$ & $16(41.0)$ & $16(41.0)$ & $30(76.9)$ & $26(66.7)$ & $30(76.9)$ \\
\hline
\end{tabular}


Similar results were obtained by $\mathrm{Cu}$ i et al. [4], who detected $55 \% \mathrm{Hbl}$-positive $B$. cereus strains isolated from raw milk samples. Interestingly, the toxigenic strains of $B$. $c$ reus have not yet been shown to produce $\mathrm{Hbl}$ as a separate enterotoxin [3].

The occurrence of B. cereus emetic syndrome is mainly associated with the consumption of rice and rice dishes, but also with foods of higher starch content, such as pasta or noodles [20]. C r e s s e y et al. [3] reported that most of the B. cereus strains are capable of producing either diarrheal or emetic toxins. In contrast, $\mathrm{B}$ e a t $\mathrm{t}$ i e and $\mathrm{W}$ i $11 \mathrm{i}$ a $\mathrm{m} \mathrm{s}$ [1] detected $36 \%$ of $B$. cereus strains capable of producing both toxins simultaneously. In our study, we detected $20.5 \%$ of emetic strains that also produced non-haemolytic enterotoxin. From this point of view, goat colostrum can be considered as a significant source of emetic B. cereus. Conversely, a relatively low proportion of emetic strains have been shown by the results of a study conducted in Sweden to monitor the occurrence of emetic toxin in B. cereus isolates from raw cow's milk samples from different farms. Of the 722 isolates, only 11 (1.5\%) emetic strains were detected [21]. The low incidence of emetic B. cereus strains was also shown in a study by $\mathrm{S}$ e o $\mathrm{n} g$ et al. [19], who detected 5 (7 \%) emetic strains among 71 food isolates.

\section{CONCLUSIONS}

Recently, the popularity of goat's milk and its products has increased. Goat colostrum is increasingly used as a part of dietary supplements. Bacillus cereus spores very well withstand adverse environmental conditions as well as many technological operations used in food production. The results of our study confirm that goat colostrum may be a significant reservoir of toxigenic $B$. cereus strains, which may be able to produce not only different types of enterotoxins but also emetic toxins under appropriate conditions. From this point of view, the occurrence of toxigenic Bacillus cereus in goat colostrum could be a risk for consumers.

\section{ACKNOWLEDGEMENT}

This study was supported by the Internal Grant Agency of the University of Veterinary and Pharmaceutical Sciences Brno (IGA VFU Brno, grant number 211/2019/FVHE).

\section{REFERENCES}

1. Beattie, S. H., Williams, A. G., 1999: Detection of toxigenic strains of Bacillus cereus and other Bacillus spp. with an improved cytotoxicity assay. Lett. Appl. Microbiol., 28, 3, 221225.

2. Beecher, D. J., Schoeni, J. L., Wong, A. C., 1995: Enterotoxic activity of hemolysin BL from Bacillus cereus. Infect. Immun., $63,11,4423-4428$.

3. Cressey, P., King, N., Soboleva, T., 2016: Risk profile: Bacillus Cereus in dairy products. MPI Technical Paper No. 2016/58, 1-112. Retrieved April 21, 2019, on the Word Wide Web https://www.mpi.govt.nz/dmsdocument/14149/send 11.

4. Cui, Y., Liu, X., Dietrich, R., Märtlbauer, E., Cao, J., Ding, S., et al., 2016: Characterization of Bacillus cereus isolates from local dairy farms in China. FEMS Microbiol. Lett., 363,12, 1-6. DOI: 10.1093/femsle/fnw096.

5. Di Pinto, A., Bonerba, E., Bozzo, G., Ceci, E., Terio, V., Tantillo, G., 2013: Occurrence of potentially enterotoxigenic Bacillus cereus in infant milk powder. Eur. Food Res. Technol., 237, 2, 275-279. DOI: 10.1007/s00217-013-1988-8.

6. Dréan, P., McAuley, C. M., Moore, S. C., Fegan, N., Fow, E. M., 2015: Characterization of the spore-forming Bacillus cereus sensu lato group and Clostridium perfringens bacteria isolated from the Australian dairy farm environment. BMC Microbiol., 15, 38, 1-10. DOI: 10.1186/s12866-015-0377-9.

7. Ghelardi, E., Celandroni, F., Salvetti, S., Barsotti, C., Baggiani, A., Senesi, S., 2002: Identification and characterization of toxigenic Bacillus cereus isolates responsible for two foodpoisoning outbreaks. FEMS Microbiol. Lett., 208, 1, 129-134. DOI: 10.1111/j.1574-6968.2002.tb11072.x.

8. Granum, E. P., Lindbäck, T., 2013: Bacillus cereus. In Doyle, M. P., Buchanan, R. L: Food Microbiology: Fundamentals and Frontiers, 4th edn., ASM Press, Washington DC, 491-502.

9. Guinebretiere, M. H., Broussolle, V., Nguyen-The, C., 2002: Enterotoxigenic profiles of food-poisoning and food-borne Bacillus cereus strains. J. Clin. Microbiol., 40, 8, 3053-3056. DOI: 10.1128\%2FJCM.40.8.3053-3056.2002.

10. Horáčková, Š., Skalka, V., Solichová, K., Čurda, L., 2015: Antimicrobial effect of cow and goat colostrum against undesirable microorganisms (In Czech). Mlékařské listy, 153, XIX-XXII.

11. Horwood, P. F., Burgess, G. W., Oakey, H. J., 2004: Evidence for non-ribosomal peptide synthetase production of cereulide (the emetic toxin) in Bacillus cereus. FEMS Microbiol. Lett., 236, 2, 319-324. DOI: 10.1016/j.femsle.2004.06.004. 
12. Keisam, S., Tuikhar, N., Ahmed, G., Jeyaram, K., 2019: Toxigenic and pathogenic potential of enteric bacterial pathogens prevalent in the traditional fermented foods marketed in the Northeast region of India. Int. J. Food Microbiol., 296, 21-30. DOI: 10.1016/j.ijfoodmicro.2019.02.012.

13. Ma, H., Li, J., Xi, X., Xu, H., Wuri, L., Bian, Y, et al., 2018: Evaluation of bacterial contamination in goat milk powder using PacBio single molecule real-time sequencing and droplet digital PCR. J. Food Prot., 81, 11, 1791-1799. DOI: 10.4315/0362-028X.JFP-17-535.

14. Martineau, F., Picard, F. J., Roy, P. H., Ouellette, M., Bergeron, M. G., 1996: Species-specific and ubiquitous DNA-based assays for rapid identification of Staphylococcus epidermidis. J. Clin. Microbiol., 34, 12, 2888-2893.

15. Organji, S. R., Abulreesh, H. H., Elbanna, K., Osman, G. E. H., Khider, M., 2015: Occurrence and characterization of toxigenic Bacillus cereus in food and infant faeces. Asian Pac. J. Trop. Biomed., 5, 7, 515-520. DOI: 10.1016/j. apjtb.2015.04.004.

16. Rowan, N. J., Anderson, J. G., 1998: Diarrhoeal enterotoxin production by psychrotrophic Bacillus cereus present in reconstituted milk-based infant formulae (MIF). Lett Appl. Microbiol., 26, 2, 161-165.

17. Rowan, N. J., Caldow, G., Gemmell, C. G., Hunter, I. S., 2003: Production of diarrheal enterotoxins and other potential virulence factors by veterinary isolates of Bacillus species associated with non-gastrointestinal infections. App. Environ. Microbiol., 69, 4, 2372-2376. DOI: 10.1128/aem.69.4.23722376.2003 .
18. Schoeni, J. L., Wong, A. C., 1999: Heterogeneity observed in the components of haemolysin $\mathrm{BL}$, an enterotoxin produced by Bacillus cereus. Int. J. Food Microbiol., 53, 2-3, 159-167.

19. Seong, S. J., Lim, J. S., Lee, K. G., Lee, S. J., Hong, K. W., 2008: Toxin gene profiling of Bacillus cereus food isolates by PCR. J. Korean Soc. Appl. Biol. Chem., 51, 4, 263-268. DOI: 10.3839/jksabc.2008.046.

20. Stenfors Arnesen, L. P., Fagerlund, A., Granum, P. E., 2008: From soil to gut: Bacillus cereus and its food poisoning toxins. FEMS Microbiol. Rev., 32, 4, 579-606. DOI: 10.1111/j.15746976.2008.00112.x.

21. Svensson, B., Monthán, A., Shaheen, R., Andersson, M. A., Salkinoja-Salonen, M., Christiansson, A., 2006: Occurrence of emetic toxin producing Bacillus cereus in the dairy production chain. Int. Dairy J., 16, 7, 740-749. DOI: 10.1016/j.idairyj.2005.07.002.

22. Yamada, S., Ohashi, E., Agata, N., Venkateswaran, K., 1999: Cloning and nucleotide sequence analysis of gyrB of Bacillus cereus, $B$. thuringiensis, B. mycoides, and B. anthracis and their application to the detection of B. cereus in rice. App. Environ. Microbiol., 65, 4, 1483-1490.

23. Zhang, F., Wang, Z., Lei, F., Wang, B., Jiang, S., Peng, Q., et al., 2017: Bacterial diversity in goat milk from the Guanzhong area of China. J. Dairy Sci., 100, 10, 7812-7824. DOI: 10.3168/jds.2017-13244.

Received May 24, 2019

Accepted July 15, 2019 